\title{
Lenalidomide-Induced Pure Red Cell Aplasia
}

\section{Lenalidomid ile Uyarılmış Eritroid Dizi Aplazisi}

\author{
Tuphan Kanti Dolai, Shyamali Dutta, Prakas Kumar Mandal, Sandeep Saha, Maitreyee Bhattacharyya \\ NRS Medical College and Hospital, Department of Hematology, Kolkata, India
}

\section{To the Editor,}

Pure red cell aplasia (PRCA) is a bone marrow failure disorder. Several drugs have been reported as having induced PRCA, but lenalidomide-induced PRCA is rarely reported. Here we present a patient with myelodysplastic syndrome (MDS) who developed PRCA after treatment with lenalidomide.

A 47-year-old male presented with a history of weakness with effort intolerance for 5 months. Examination showed pallor and mild splenomegaly. Blood count showed $\mathrm{Hb}$ level of $86 \mathrm{~g} / \mathrm{L}$, total WBC count of $5.2 \times 10^{9} / \mathrm{L}$, normal differential counts, and platelet count of $223 \times 109 / \mathrm{L}$. MCV was $101 \mathrm{fL}$ and reticulocyte count was $1 \%$. Serum chemistries were normal. Bone marrow aspiration and biopsy results showed mild hypercellularity with evidence of megaloblastic erythropoiesis and dyserythropoiesis. Cytogenetics showed loss of the $\mathrm{Y}$ chromosome. Iron stores were normal. Serum B12, folic acid, and serum ferritin levels were normal. Tests for antinuclear antibodies, HIV-1 and HIV-2 antibodies, hepatitis B surface antigen, and anti-hepatitis $C$ virus were negative. Expressions of CD55 and CD59 on granulocytes were in the normal range. He received vitamin $\mathrm{B} 12$ with no success. With the diagnosis of MDS with refractory anemia, he was started on lenalidomide at $5 \mathrm{mg}$ daily.

In the next 3 weeks, he presented with severe weakness and the $\mathrm{Hb}$ level dropped to $53 \mathrm{~g} / \mathrm{L}$ with normal WBC and platelets. Reticulocyte count was $<1 \%$. Concentrated RBCs were transfused and he was re-evaluated. A repeat bone marrow aspiration and biopsy revealed severely depressed erythropoiesis (erythroid precursors of $<5 \%$ ) and dysplastic megakaryocytes. Parvovirus antibody (IgM) was negative. As there were no other inciting factors for
PRCA, we stopped the lenalidomide. Oral prednisolone at $1 \mathrm{mg} / \mathrm{kg}$ was started and given for 8 weeks, with which $\mathrm{Hb}$ levels returned to the pre-PRCA range. Repeated aspiration showed normal erythropoiesis with dyserythropoiesis. Steroids were tapered over the next 2 months and the patient is still under follow-up and doing well, with $\mathrm{Hb}$ levels ranging between 80 and $95 \mathrm{~g} / \mathrm{L}$ without transfusion support. Informed consent was obtained.

Here we report a patient with MDS who was treated with lenalidomide and developed PRCA, which improved with withdrawal of the drug and treatment with corticosteroids. In the literature to date, only one case has been reported of lenalidomide-induced PRCA [1]. Re-challenging the patient with lenalidomide might have given additional evidence about this phenomenon, but this was not justifiable.

The most common offensive drugs are erythropoietin, phenytoin, isoniazid, azathioprine, and zidovudine [2]. The pathogenesis of development of drug-induced PRCA is unknown; it may be due to direct effects of the drug per se, induction of autoimmunity, or specific inhibitory effects on DNA synthesis, probably at the step of deoxyribonucleotide formation [3]. Although there are no guidelines for the management of drug-induced PRCA, discontinuation and steroids may be of benefit [4].

Key Words: Lenalidomide, PRCA, MSD

Anahtar Kelimeler: Lenalidomid, PRCA, MDS

\section{Conflict of Interest Statement}

The authors of this paper have no conflicts of interest, including specific financial interests, relationships, and/ or affiliations relevant to the subject matter or materials included.

Address for Correspondence: Tuphan Kanti DOLAI , M.D.,

NRS Medical College and Hospital, Department of Hematology, Kolkata, India

Phone: +913322266118 E-mail: tkdolai@hotmail.com

Received/Geliş tarihi : June 14, 2013

Accepted/Kabul tarihi : August 19, 2013 


\section{References}

1. Raza A, Reeves JA, Feldman EJ, Dewald GW, Bennett JM, Deeg HJ, Dreisbach L, Schiffer CA, Stone RM, Greenberg PL, Curtin PT, Klimek VM, Shammo JM, Thomas D, Knight RD, Schmidt M, Wride K, Zeldis JB, List AF. Phase 2 study of lenalidomide in transfusion-dependent, low-risk, and intermediate-1-risk myelodysplastic syndromes with karyotypes other than deletion 5q. Blood 2008;111:86-93.
2. Thompson DF, Gales MA. Drug induced pure red cell aplasia. Pharmacotherapy 1996;16:1002-1008.

3. Fisch P, Handgretinger R, Schaefer HE. Pure red cell aplasia. Br J Haematol 2000;111:1010-1022.

4. Ammus SS, Yunis AA. Acquired pure red cell aplasia. Am J Hematol 1987;24:311-326. 